\begin{tabular}{|l|l|l|}
\hline Received : October 2019 & Accepted: April 2020 & Published : July 2020
\end{tabular}

\title{
Pengaruh Learning Organization dan Innovation Strategy terhadap Daya Saing Budidaya Bawang Putihdi Kabupaten Temanggung
}

\author{
Arief Kurniawan $^{1 *}$, Ivan Yulivan ${ }^{2 *}$ Jubaedah $^{3 *}$ \\ ${ }^{1}$ Mahasiswa Program Studi Magister Manajemen Fakultas Ekonomi dan Bisnis, Universitas \\ Pembangunan Nasional "Veteran" Jakarta \\ ${ }^{2}$ Program Studi Ekonomi Pertahanan Universitas Pertahanan \\ ${ }^{3}$ Fakultas Ekonomi dan Bisnis, Universitas Pembangunan Nasional “Veteran” Jakarta \\ *E-mail: akurniawan@pertanian.go.id
}

\begin{abstract}
The problems faced in the development of garlic production in Temanggung regency are the competitiveness of garlic is still low. This study aims to determine the effect of The Learning Organization and Innovation Strategy on Garlic CultivationCompetitiveness in The Temanggung Regency. The study was conducted with a total sample of 73 farmer groups from 90 existing farmer groups in 3 garlic center districts, namely The Bulu District, The Parakan District, and The Kledung District. Data processing uses Structural Equation Modeling (SEM) analysis using the Partial Least Square (PLS) approach. The results of the analysis in this study indicate that (1) There is no direct influence of Learning Organization on Garlic Cultivation Competitiveness, (2) there is a direct effect of Innovation Strategy on Garlic CultivationCompetitiveness, (3) there is an indirect influence of The Learning Organzation on Garlic CultivationCompetitiveness through Innovation Strategy, and (4) there is a direct influence of The Learning Organizations on Innovation Strategy.
\end{abstract}

Keywords:The Learning Organization, Innovation Strategy, Competitiveness, and Garlic Cultivation.

\begin{abstract}
Abstrak
Permasalahan pengembangan produksi bawang putih di kabupaten Temanggung adalah daya saing bawang putih yang masih rendah. Hal ini disebabkan karena kemampuan petani bawang putih yang belum memadai dan kelembagaan kelompok petani bawang putih belum dapat menciptakan strategi inovasi dalam pemanfaatan teknologi budidaya bawang putih. Studi ini bertujuan untuk untuk mengetahui pengaruh Learning Organizationdan, Innovation Strategyterhadap daya saing bawang putihdi kabupaten Temanggung. Penelitian dilakukan dengan jumlah sampel sebanyak 73 kelompok tani dari 90 kelompok tani yang ada di 3 kecamatan sentra bawang putihyaitu kecamatanBulu, kecamatan Parakan, dan kecamatan Kledung. Anaisisdata menggunakan analisis Structural Equation Modelling (SEM) dengan pendekatan Partial Least Square (PLS). Hasil analisis pada penelitian ini menunjukkan bahwa (1) tidak ada pengaruh langsung Learning Organization terhadap Daya Saing bawang putih, (2) terdapat pengaruh langsung Innovation Strategy terhadap daya saing budidaya bawang putih, (3) terdapat pengaruh tidak langsung Learning Organzation terhadap daya saingbudidaya bawang putihmelalui Innovation Strategy, dan (4) terdapat pengaruh langsung Learning Organization terhadap Innovation Strategy.
\end{abstract}

Kata kunci:Organisasi Pembelajar, Strategi Inovasi, Daya Saing, dan Budidaya Bawang Putih

\section{Pendahuluan}

Kabupaten Temanggung merupakan salah satu wilayah yang dimana kawasan pertanian menjadi salah satu sektor pembangunan ekonomi yang signifikan. Hal ini ditunjukkan oleh kontribusi sektor pertanian tahun 2017 adalah sebesar 24,30\% dari nilai total PDRB kabupaten Temanggung sesuai data distribusi persentase produk domestik regional bruto Temanggung atas dasar harga berlaku menurut lapangan usaha, 2013-2017. Prosentasi tersebut termasuk dalam 
kategori tinggi, mengingat kontribusi sektor pertanian tersebut berada pada kedua setelah sektor industri pengolahan sebesar $27,05 \%$. Ini menunjukkan bahwa potensi pertanian di wilayah tersebut didukung dari subsektor pertanian hortikultura. Subsektor hortikultura memiliki peran strategis dalam menopang sektor ekonomi karena potensi komoditas hortikultura tersedia secara melimpah dan diproduksi sepanjang tahun. Dilihat dari aspek perannya, komoditas hortikultura menjadi pemasok bahan baku industri, penyerap tenaga kerja dan utamanya sebagai pemenuh kebutuhan pangan. Produk pertanian hortikultura merupakan produk pertanian yang memiliki potensi yang bernilai ekonomis dan berorientasi pasar yang tinggi.

Salah satu komoditas hortikultura di kabupaten Temanggung adalah bawang putih. Kabupaten Temanggung merupakan produsen bawang putih terbesar di provinsi Jawa Tengah dengan ratarata produksi 57.848 ton selama tahun 2017 sesuai dengan data pada Tabel 1.

Tabel 1. Rata-rata Luas Panen, Produksi, Produktivitas bawang putih di Jawa Tengah Tahun 2017

\begin{tabular}{|c|c|c|c|}
\hline Kabupaten & Luas Panen (ha) & Produksi (ton) & Produktivitas (ton/ha) \\
\hline Temanggung & 846 & 57.848 & 68,38 \\
\hline Karanganyar & 114 & 16.188 & 142,00 \\
\hline Magelang & 31 & 1.345 & 43,39 \\
\hline Tegal & 19 & 1.032 & 54,32 \\
\hline Wonosobo & 16 & 794 & 49,63 \\
\hline Brebes & 12 & 1.220 & 101,67 \\
\hline Wonogiri & 9 & 587 & 65,22 \\
\hline Pemalang & 6 & 466 & 77,67 \\
\hline Kendal & 2 & 160 & 80,00 \\
\hline Jawa Tengah & 1.055 & 79.640 & 75,49 \\
\hline
\end{tabular}

Sumber: BPS provinsi Jawa Tengah (2017)

Sesuai data pada tabel 1 diatas, tingginya produksi bawang putih di kabupaten Temanggung didukung oleh luas panen yang lebih besar dibandingkan daerah lain. Akan tetapi rata-rata produktivitas bawang putih di kabupaten Temanggung sebesar 68,38 ton/ha masih kalah apabila dibandingkan dengan rata-rata produktivitas bawang putih di kabupaten Karanganyar sebesar 142 ton/ha, kabupaten Brebes sebesar 101,67 ton/ha, kabupaten Kendal sebesar 80 Ton/ha, dan kabupaten Pemalang sebesar 77,67 ton/ha dimana luas panen dan produksi bawang putih di keempat kabupaten tersebut lebih kecil daripada luas panen dan produksi bawang putih di kabupaten Temanggung.

Kondisi ini menunjukkan bahwa produktivitas bawang putih di kabupaten Temanggung masih rendah dan perlu ditingkatkan, mengingat potensi sumberdaya yang tersedia untuk pengembangan komoditas bawang putih. Menurut Adrianto (2016) menyatakan bahwa produktivitas yang rendah dapat disebabkan oleh beberapa faktor antara lain belum tercapainya efisiensi teknis dan adanya inefisiensi teknis dalam mengalokasikan input produksi serta terbatasnya teknologi produksi yang berpengaruh terhadap peningkatan produksi.

Wardani (2018) menyatakan bahwa faktor yang mempengaruhi rendahnya produktivitas bawang putih di kabupaten Temanggung adalah kelompok petani (poktan) bawang putih di kabupaten Temanggung belum seluruhnya menerapkan kaidah budidaya yang benar (GAP) sesuai rekomendasi dan sebagian besar masih menerapkan sistem budidaya konvensional. 
Intensifikasi budidaya bawang putih diarahkan pada penerapan Good Agricultural Practices (GAP) dan Standar Operasional Prosedur (SOP). Pedoman GAP tertuang dalam Peraturan Menteri Pertanian Nomor 48/Permentan/OT.140/10/2009 tentang Pedoman Budidaya Buah dan Sayur yang Baik. GAP berfungsi sebagai panduan dasar bagi petani dalam menjalankan budidaya buah dan sayur.

Dari aspek kelembagaan kelompok petani (poktan), hingga saat ini jumlah petani bawang putih di kabupaten Temanggung sebanyak 143 kelompok tani yang berdomisili di 11 kecamatan. Jumlah poktan yang terbentuk belum sepenuhnya dapat membantu kegiatan petani dalam mengembangkan usaha taninya. Demikian juga lembaga permodalan dan koperasi belum berkembang di kawasan sentra produksi sehingga belum mampu memenuhi kebutuhan usaha tani terutama penyediaan saprodi dan membantu dalam pemodalan dan pemasaran. Rendahnya produksi bawang putih dipicu juga oleh masuknya bawang putih impor dan bergesernya preferensi konsumen terhadap bawang putih impor, sehingga bawang putih lokal kurang diminati. Kondisi ini menyebabkan berkurangnya minat petani untuk mengusahakan bawang putih, akibatnya terjadi penurunan luas panen bawang putih setiap tahunnya (Pramono dkk, 2011). Dari aspek nilai ekonomis, berdasarkan data hasil Analisis Usaha Tani (AUT) bawang putih yang dirilis oleh SubDit bawang Ditjen Hortikultura 5 April 2018, terhadap 10 kabupaten sentra produksi bawang putih di Indonesia, diperoleh nilai BEP bawang putih (Rp/kg) sebesar Rp13.721,-. Dibandingkan dengan BEP bawang putih impor dari China sebesar Rp Rp. 6.381,s.d. Rp. 8.508,- , India sebesar Rp 2.101,- , dan Bhanglades sebesar Rp3.219,-. Hal ini menunjukkan bahwa daya saing bawang putih masih sangat lemah.

Kelompok Petani bawang putih tidak cukup berdaya disebabkan karena aspek kualitasnya kalah bersaing dengan produk impor dan kelemahan kelompok petani dalam pengetahuan strategi inovasi dalam pengembangan bawang putih yang mampu mendorong produksi bawang putih. SDM pemulia tanaman (penangkar benih) masih sedikit dan belum mampu menghasilkan inovasi yang berdaya saing. Pengembangan terhadap kemampuan petani bawang putih tidak hanya dilakukan untuk meningkatkan pengetahuan dalam penerapan teknologi, tetapi juga untuk meningkatkan inovasi, motivasi, dan persepsi tentang pertanian modern, serta untuk perbaikan sikap/moral, transformasi budaya menjadi pertanian berbudaya industri (Renstra Puslitbanghorti 2014-2019).

Kelompok petani bawang putih masih berdaya saing lemah dibanding pelaku usaha lainnya. Hal ini disebabkan oleh lemahnya fungsi atau peran dari lembaga pertanian hortikultura (poktan, gapoktan, asosiasi). Kesadaran petani untuk berkolaborasi masih rendah serta peran dari beberapa lembaga yang sudah terbentuk (sebagai contoh: Dewan Hortikultura Nasional, Asosiasi Eksportir dan Importir, koperasi dan lainnya) masih belum optimal.

Untuk dapat berdaya saing tinggi dapat dilakukan dengan memaksimalkan peran kelompok tani sebagai lokus dari pengetahuan dan menjadikannya sebagai knowledge worker, sehingga mampu menumbuhkan proses pembelajaran bagi kelompok petani, tercipta proses knowledge sharing antara kelompok petani, terwujudnya budaya organisasi dalam kelembagaan kelompok petani mendukung proses dan aktivitas usaha tani bawang putih, dan tumbuh inovasi dan ide yang mendukung pengembangan usaha tani bawang putih melalui inovasi teknologi dan optimalisasi lahan di kabupaten Temanggung.

Hal inilah yang menjadi latar belakang perlunya meneliti mengenai proses Learning Organizationdengan melihat aspek SDM Kelompok Tani Bawang Putih dalam menciptakan Strategi Inovasi (Innovation Strategy) melalui pemanfaatan teknologi dan optimalisasi lahan untuk mengetahui pengaruh Learning Organization terhadap inovasi dan daya saing budidaya bawang putih di Kabupaten Temanggung. 
Studi ini bertujuan untuk untuk mengetahui pengaruh Learning Organizationdan Innovation Strategyterhadap daya saing budidaya bawang putihdi kabupaten Temanggung. Penelitian dilakukan dengan jumlah sampel sebanyak 73 kelompok tani dari 90 kelompok tani yang ada di 3 kecamatan sentra bawang putih yaitu kecamatan Bulu, kecamatan Parakan, dan kecamatan Kledung.

\section{Landasan Teori}

\subsection{The Learning Organization}

Learning Organizationmenurut Harper dan Glew (2008),merupakanorganisasi yang berkemauan kuat untuk meningkatkan kinerja organisasimelalui inovasi terhadap hal-hal baru untuk dilakukan atau cara yang baru untukmelakukan proses bisnis dalam organisasi. Transformasi pengetahuan dalam organisasi pembelajar harusberada diantara anggota dalam organisasi dimana masing-masing individu dalam organisasi memiliki keterkaitan dalam organisasi melalui visi bersama dan pandangan atas visi secara utuh (Ortenblad,2001). Selain itu, Ortenblad (2001), juga menjelaskan bahwa Learning Organizationmerupakan setiap orang yang belajar dimana pengetahuan terkandung di dalam dan diluar pribadi orang tersebut. Watkins dan Marsick (2003), yang disetasi Chajnacki (2007), menjelaskanbentuk dari Learning Organizationterdiri dari tujuh Dimensions of Learning Organization Questionnare (DLQQ), salah satu dimensi yang terkait dengan kelompok individu adalah Encourage Collaboration and Team Learning dimana melalui kelompok, setiap anggota kelompok akan belajarbagaimana berkolaborasi, memperluas kapasitas organisasi untukmenerima arahan dalam aktivitas organisasi secara terpadu untuk mencapai tujuan.

Maholtra (1996), Learning Organizationmerupakan kumpulan individu dalam organisasi yang secara kontinyu melakukan perbaikan diri terhadap kompetensi diri sehingga mampu berinovasi, dan Hacket (2000), menyatakan bahwa Organization Learning adalah prosesorganisasi dalam beradaptasi terhadap perubahan dan kemamampuan organisasi untuk berkembang ke arah yang lebih baik dengan menciptakan dan mengaplikasikan hal-hal baru seperti pengetahuan, kemampuan, dan kompetensi serta mampu menyampaikan hal - hal baru tersebut kepada kolega lainnya.

Menurut Senge (1990), Learning Organizationakan berhasil dan berpengaruh positif pada organisasi apabilia memiliki karakteristik sebagai berikut: 1) Pembelajaran individu terlaksana dengan baik, 2) Adanya proses berbagi pengatahuandengan baik antar individu, 3) Budaya organisasi mendukung proses dan aktivitas pembelajaran, 4) Anggota organisasi memperoeh motivasi dan diberikan kesempatan berfikir kritis dan berani mengambil resiko terhadap inovasi dan ide yang dilaksanakan, dan5) Organisasi memposisikan karyawan berkontribusi penting dalam menunjang kemajuan organisasi.

Learning Organizationakan bermanfaat terhadap organisasi antara lain:a) lingkungan organisasi menjadi dinamis dan proaktif, b) karyawan berkemampuan baik dan berkualitas, c) karyawan memiliki komitmen dan integritas tinggi, d) karywan bersinergi secara bersama mewujudkan visi organisasi, e) kinerja karyawan meningkat, dan f) setiap indivisu siap mengembangkan kapasitas dan kapabilitas.

Sesuai hasil penelitian Sirait, dkk (2015), meneliti terkait dengan masalah dalam proses bisnis yang dihadapi oleh Usaha Kecil Menengah (UKM) terkait dengan kelemahan sumberdaya manusia misalnya kurangnya pengetahuan dan informasi yang dimiliki sehingga mempengaruhi kinerja UKM. Penelitian ini bertujuan untuk menganalisis pengaruh dari Learning Organization dan inovasi terhadap kinerja UKM di Kota Bogor. Penelitian tersebut menyimpulkan bahwa penerapan Learning Organizationpada UKM di Kota Bogor mempengaruhi inovasi dan kinerja UKM di Kota Bogor. Melalui Learning Organization, hal itu 
akan meningkatkan kompetensi dan kreativitas individu dalam UKM, berdampak pada hasil proses dan produk yang inovatif, dan mampu bersaing secara nasional maupun pesaing dari luar negeri.

\subsection{Strategi Inovasi (Innovation Strategy)}

Soleh (2008), strategi didefinisikan sebagai proses utama dalam menyelesaikan berbagai permasalahan atau titik - titik kritis dari aktivitas organisasi dan upaya mengantisipasi kondisi masa depan yang cenderung tidak pasti dan sulit diprediksi. Melalui strategi organisasi telah berupaya mengeksplorasi potensi untuk memaksimalkan output yang ingin dicapai sekaligus mengembangkan kemampuan dalam beradaptasi dengan perubahan lingkungan yang sangat cepat.

West(1997), mendefinisikan inovasi merupakan pengenalan dan penerapan terencana dalam suatu pekerjaan, tim atau organisasi, dari berbagai ide, sekumpuan proses,berbagai macam produk, atau mekanisme serta prosedur baru bagi pekerjaan, tim, atau organisasiituuntuk memberikan keuntungan dalam pekerjaan, tim, atau organisasi itu sendiri.Jadi inovasi bermuka dari suatu gagasandari dalam maupun dari luar organisasi untuk menciptakan dan menerapkan sesuatu yang baru, sehingga memberikan manfaat dan pengaruh positif bagi organisasi. Jadiunsur penting inovasi adalah gagasan, penerapan dan kegunaan.

West (2000) dalam Buulolo (2018), menyatakan bahwa inovasi mempengaruhi secara kuat dan konsisten pada kinerja usaha. Artinya semakin kuat proses inovasi maka semakin meningkat kinerja perusahaan. Sudah menjadi kepercayaan bahwa perusahaan yang ingin bersaing dalam banyak bidang usaha seharusnya mampu mengembangkan strategi-strategi yang inovatif. Survei menunjukkan bahwa tahap inovasi masih rendah dan terjadi resistensi terhadap perubahandi beberapa perusahaan. Hal - hal yang mampu mendorong inovasi dalam perusahaan berupa:

a. Lingkungan Perusahaan, yaitu pabrik-pabrik yang memiliki pasarrendah lebih besar kemungkinannya berinovasi melalui inovasi yang dapat bersifat reaktif, adaptif atau serentak.

b. Kualitas, khususnya dalam kaitan dengan pemeriksaan kualitas pada hasil akhir (output) dan tiap-tiap proses kerja.

c. Kerjasama tim, berupaya untuk mengenalkan dan mengembangkan kerjasama tim sehingga mempengaruhi proses berinovasi.

d. Komunikasi dalam bentuk koordinasi antar jabatan dan pertemuan berkala akan mempengaruhi pengembangan inovasi

e. Dukungan manajemen, berupa komitmen dan dukungan yang berdampak pada kinerja karyawan dalam berinovasi;

f. Keterbukaan, mengembangkan asas, strategi dan informasi yang terbuka untuk dipertanyakan.

g. Partisipasi, yaitu upaya untuk menumbuhkan rasa memiliki, saling menghormati, dan menghilangkan prasangka diantara pekerja dan manajemen perusahaan.

Sedyowidodo, dkk (2013), Perilaku Inovatif, secara anatomis dan psikologis manusia tidak banyak berbeda. Persamaan secara anatomis dan psikologis ini mengarah kepada terjadinya proses tingkah laku yang sama pula pada setiap manusia. Melalui perilaku inovatif, maka keterikatan individu akan terjaga dengan baik dan proses penyatuan pengetahuan yang dimiliki dari berbagai sumber dapat diberikan kepada perusahaan. Semangat berperilaku inovatif juga akan meningkatkan tingkatan modal kecerdasan seseorang dari hanya tahu apa (know what) menjadi menjadi peduli mengapa (care why) dan akan terwujudkan suatu organisasi yang cerdas 
(intelligent corporation). Nugroho (2013), Berperilaku Inovatif menguatkan dalam mengembangkan dan mempertahankan keunggulan kompetitif (Tidd et al., 2001).

\subsection{Daya SaingBudidaya Bawang Putih}

Indrayani dan Swara (2014), preferensi konsumen mengenai ukuran bawang putih memberikan suatu tantangan tersendiri. Para peneliti pemulia/breeder dituntut untuk mencari varietas bawang putih yang memiliki ukuran besar seperti bawang putih impor. Peneliti budidaya juga dituntut untuk untuk menemukan suatu cara dan teknologi budidaya bawang putih yang baik agar dapat menghasilkan bawang putih yang sesuai dengan preferensi konsumen. Selain itu preferensi konsumen terhadap harga juga merupakan suatu tantangan bagi para pembuat kebijakan untuk membuat nilai jual bawang putih lokal dapat mengungguli harga jual bawang putih impor. Penting untuk menciptakan rantai pemasaran bawang putih yang efektif dan efisien sehingga tidak timbul banyak biaya pemasaran yang dirasa tidak perlu, sehingga harga bawang putih dapat ditekan serendah-rendahnya. Dari segi perdagangan internasional, jumlah konsumsi, jumlah produksi, nilai tukar rupiah terhadap dollar, dan PDB Pertanian berpengaruh signifikan terhadap impor bawang putih Indonesia.

Noor (2018), petani bawang putih agar dapat bersaing dengan bawang putih impor yang berkualitas baik dan memiliki bentuk yang besar-besar maka diperlukan berbagai usaha untuk dapat membudidayakan bawang putih yang berkualitas baik dan tidak kalah dengan bawang putih impor. Bawang putih yang berkualitas baik dapat diperoleh dengan benih yang baik pula. Diperlukan banyak penelitian untuk memperoleh benih yang baik. Setelah diperoleh benih yang baik perlu dilakukan sertifikasi benih untuk budidaya bawang putih kualitas baik sehingga dapat menekan angka impor bawang putih Indonesia agar perlahan petani bawang putih dapat mewujudkan swasembada bawang putih sehingga Indonesia tidak lagi perlu mengimpor bawang putih.

Saptana (2010), daya saing (competitiveness) dapat didefinisikan kemampuan bersaing dalam perspektif ekonomi, politik dan strategi bisnis perusahaan atau industri. Selanjutnya, para ekonom memaknai keunggulan kompetitif merupan hasil kombinasi atas distorsi pasar dan keunggulan komparatif (comparative advangtage). Daya saing diartikan sebagai kemampuan pada sektor industri dan perusahaan untuk bersaing mencapai pertumbuhan berkelanjutan didalam lingkungan secara menyeluruh dengan prasarat bahwa biaya-biaya yang sejenis lebih rendah dari penerimaan sumber daya yang digunakan.

Erwidodo (2015),selain sebagai faktor menopang produktivitas dan efisiensi biaya, komponen/daya saing yang melekat di komoditashortikultura berupa kualitas atau standar mutu. Peningkatan kualitas dan standar mutu dilakukan secara instan tetapi mulai dari pengembangan dan pemilihan varietas sampai kepada teknis budidaya dan pasca panen.

Berdasarkan kacamata mikro, daya saing dipengaruhi oleh: (1) keunggulan statik (static advantage), berupa sumber daya, karyawan, dan lokasi yang strategis; dan (2) keunggulan pembelajaran (learning advantage) berupa pendidikan \& latihan, pengalaman/kearifan lokal, dan penelitian untuk mendapatkan inovasi-inovasi baru.

\section{Metodologi}

Penelitian ini merupakan penelitian kuantiatif untuk melihat hubungan sebab akibat antara independent variabel dan dependen variabel menggunakan variabel perantara (intervening variabel). Learning Organization (LO) menjadi independen variabel, Innovation Strategy (IS) sebagai intervening variabel, dan Daya Saing bawang putih (DS) sebagai dependen variabel. 
Pemilihan lokasi penelitian dilakukan dengan metode stratified random sampling atau pengambilan sampel dengan memperhatikan suatu tingkatan (strata) pada elemen populasi. Penelitian ini mengambil lokasi di kabupaten Temanggung dengan pertimbangan - pertimbangan sebagai berikut:

a. Kabupaten Temanggung merupakan salah satu daerah penghasil bawang putih dengan produksi tertinggi di provinsi Jawa Tengah.

b. Terdapat 7 (tujuh) kecamatan di kabupaten Temanggung yang menghasilkan bawang putih, seperti yang ditunjukkan tabel 2. Lokasi penelitian ditentukan berdasarkan 3 kecamatan yang memiliki jumlah produksi dan luas panen yang terbesar di kabupaten Temanggung. kecamatan Kledung, kecamatan Parakan, dan kecamatan Bulu merupakan tiga wilayah sentra bawang putih dengan produksi terbesar dibandingkan kecamatan-kecamatanlain di kabupaten Temanggung.

Tabel 2. Data Produksi bawang putih di kabupaten Temanggung Tahun 2017

\begin{tabular}{lll}
\hline \multicolumn{1}{c}{ Kecamatan } & Luas Panen (ha) & Produktivitas (ton/ha) \\
\hline 1. Kledung & 475 & $3.507,18$ \\
\hline 2. Parakan & 55 & 465,94 \\
\hline 3. Candiroto & 12 & 81,60 \\
\hline 4. Bulu & 41 & 302,90 \\
\hline 5. Tembarak & 7 & 49,00 \\
\hline 6. Tretep & 43 & 253,80 \\
\hline 7. Ngadirejo & 7 & 49,00 \\
\hline
\end{tabular}

Sumber: BPS kabupaten Temanggung dalam angka (2018)

Berdasarkan data pada tabel 2, diketahui bahwa populasi dalam penelitian ini adalah kelompok petani (poktan) bawang putih yang berada di wilayah 3 sentra produksi bawang putih terbesar dari 7 kecamatan yaitu kecamatam Kledung, kecamatan Parakan, dan kecamatan Bulu yang berjumlah sebanyak 90 kelompok tani. Metode untuk menentukan jumlah sampel mengikuti kaidah rumus Slovin (Sevilla et. al., 1960). Perhitungan jumlah sampel berdasarkan rumus Slovin adalah $90 /(1+(90 \times 0,052))=73$ kelompok tani. Analisis pembahasan dalam penelitian ini berbasis kelompok tani yang diwakili oleh pengurus kelompok tani dari unsur ketua kelompok tani atau sekretaris kelompok tani atau anggota kelompok tani sebagai representatif dari perwakilan kelompok tani.

Instrumen dalam penelitian ini sesuai dengan referensi yang dijabarkan pada landasan teori mengenai Learning Organization, Strategi Inovasi, dan Daya Saing Budidaya Bawang Putih dapat dijabarkan sebagai berikut:

Tabel 3. Instrumen Penelitian

\begin{tabular}{|c|c|c|c|}
\hline Variabel & Dimensi & Indikator & Referensi \\
\hline $\begin{array}{l}\text { Learning } \\
\text { Organizationan }\end{array}$ & $\begin{array}{l}\text { Knowledge } \\
\text { Sharing }\end{array}$ & $\begin{array}{l}\text { Memiliki ide-ide inovasi, pengetahuan } \\
\text { kekinian terkait dengan proses bisnis } \\
\text { mulai dari inpt produksi, pengolahan } \\
\text { lahan, proses panen, pasar, } \\
\text { administrasi keuangan, dan teknologi } \\
\text { informasi }\end{array}$ & 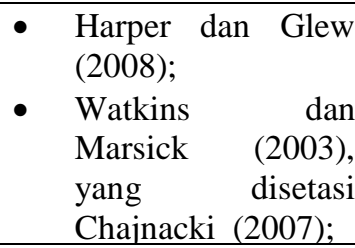 \\
\hline
\end{tabular}




\begin{tabular}{|c|c|c|c|}
\hline & Kolaborasi & $\begin{array}{l}\text { Keinginan kerjasama sesama } \\
\text { kelompok, antara kelompok, lembara } \\
\text { keuangan, dan lembaga riset }\end{array}$ & \\
\hline & $\begin{array}{l}\text { Budaya } \\
\text { Organisasi }\end{array}$ & $\begin{array}{l}\text { nilai-nilai sosial yang membentuk } \\
\text { perilaku yang berdampak pada } \\
\text { motivasi kelompok tani dalam usaha } \\
\text { tani bawang putih }\end{array}$ & \\
\hline & Kompetensi & $\begin{array}{l}\text { Pengetahuan dan Ketrampilan terkait } \\
\text { dengan usaha tani bawang putih. }\end{array}$ & \\
\hline & Konektivitas & $\begin{array}{l}\text { Jejaring yang memanfaatkan teknologi } \\
\text { informasi dan sosial budaya }\end{array}$ & \\
\hline & Kepemimpinan & $\begin{array}{l}\text { Kepercayaan yang dibangun kepada } \\
\text { pemimpin pada level kelompok tani, } \\
\text { sosial masyarakat, dan pemerintah }\end{array}$ & \\
\hline \multirow[t]{4}{*}{ Strategi Inovasi } & $\begin{array}{l}\text { Implementasi } \\
\text { Ide/Gagasan Baru }\end{array}$ & $\begin{array}{l}\text { Ide atau gagasan baru yang mengarah } \\
\text { kepada perubahan tatacara } \\
\text { pengembangan bawang outih baik dari } \\
\text { aspek budidaya dan posca panen. }\end{array}$ & \multirow{4}{*}{$\begin{array}{ll}\text { - } & \text { Soleh (2008); } \\
\text { - } & \text { West (1997); } \\
\text { - } & \text { West (2000) dalam } \\
& \text { Buulolo (2018); } \\
\text { - } & \text { Sedyowidodo, dkk } \\
& \text { (2013); } \\
\text { - } & \text { Nugroho (2013); }\end{array}$} \\
\hline & $\begin{array}{l}\text { Implementasi } \\
\text { Prosedur / Teknik } \\
\text { Budidaya baru }\end{array}$ & $\begin{array}{l}\text { Implementasi prosedur / teknik } \\
\text { pemanfaatn teknologi baru dalam } \\
\text { budidaya bawang putih }\end{array}$ & \\
\hline & $\begin{array}{l}\text { Perilaku Inovatif } \\
\text { memanfaatkan } \\
\text { Teknologi }\end{array}$ & $\begin{array}{l}\text { Cara/Ide inovatif yang dikembangkan } \\
\text { petani dalam pemanfaatan teknologi } \\
\text { informasi dalam pengolahan dan pasca } \\
\text { panen }\end{array}$ & \\
\hline & $\begin{array}{l}\text { Solusi Kreatif atas } \\
\text { masalah yang } \\
\text { dihadapi }\end{array}$ & $\begin{array}{l}\text { Kendala-kendala dalam budidaya } \\
\text { bawang putih di arahkan dengan } \\
\text { mencari solusi yang kreatif }\end{array}$ & \\
\hline \multirow{3}{*}{$\begin{array}{l}\text { Daya Saing } \\
\text { Bawang Putih }\end{array}$} & Keunggulan & Harga, Efisiensi Biaya Produksi, Nilai & \multirow{3}{*}{$\begin{array}{ll}\text { - } & \text { Indrayani dan } \\
& \text { Swara (2014); } \\
\text { - } & \text { Noor (2018); } \\
\text { - } & \text { Saptana (2010); } \\
\text { - } & \text { Erwidodo (2015) } \\
\end{array}$} \\
\hline & Kompetitif & Keuntunagn yang diperoleh & \\
\hline & $\begin{array}{l}\text { Keunggulan } \\
\text { Komparatif }\end{array}$ & $\begin{array}{l}\text { Perbandingan dengan produk bawang } \\
\text { di kabupaten lain, provinsi lain, dan } \\
\text { negara lain. }\end{array}$ & \\
\hline
\end{tabular}

Berdasarkan instrumen yang telah diperoleh di atas maka model hubungan antar varibel dalam penelitian ini dijelaskan pada gambar 1 sebagai berikut:

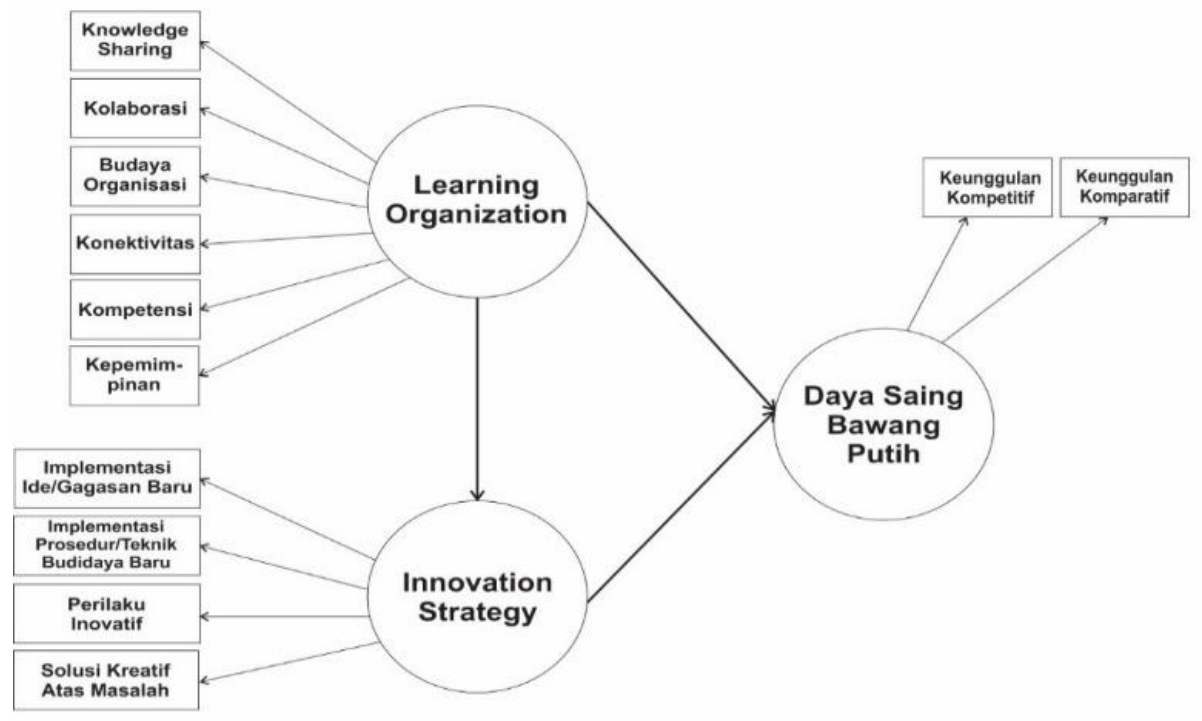

Gambar 1.Hubungan Antara Variabel 
Alat analisis yang digunakan adalah Partial Least Squares (PLS). Menurut Wold (1985) dalam Ghozali (2015), PLS merupakan alat analisis yang berdaya karena meniadakan asumsi-asumsi OLS (Ordinary Least Squares) regresi, seperti data harus terdistribusi normal serta multivarian dan tidak adanya permasalahan multikolonieritas antar variabel eksogen. Wold mengembangkan PLS sebagai alternatif modeling untuk menguji dasar teori yang lemah dan dapat digunakan untuk sampel yang sedikit atau adanya masalah normalitas data. PLS digunakan untuk menganalisa ada tidaknya hubungan antar variabel laten (prediction) pada konstruk yang dibentuk melalui indikator reflektif dan formatif. PLS juga digunakan untuk mengkonfirmasi teori (Chin dan Newsted, 1999) dalam Ghozali (2015).Permodelan dalam analisis PLS terdiri dari model pengukuran (measurement model) atau yang biasa disebut outer model dan model struktural (structural model) atau inner model.Outer model pengukuran yang menghubungkan indikator dengan variabel lantennya. Sedangkan inner model menunjukkan nilai estimasi hubungan antar variabel lanten. Adapun tahapan analisis dijelaskan sebagai berikut:

\section{a. Evaluasi Outer Model}

Model ini memperjelas hubungan antara variabel laten dengan indikator-indikatornya. Uji yang dilakukan pada model ini adalah:

\section{1) Uji Validitas}

Validitas kontsruk menjelaskan bagaimana hasil yang diperoleh dari penggunaan suatu pengukuran sesuai teori yang digunakan untuk mendefinisikan suatu konstruk.

\section{a) Validitas konvergen}

Validitas konvergen berkaitan dengan prinsip bahwa hasil pengukuran suatu konstruk seharusnya berkorelasi tinggi. Dalam outer model terdapat dua jenis indikator yaitu reflektif dan formatif. Uji validitas konvergen dengan indikator reflektif dinilai berdasarkan loading factor (korelasi antara skor item/skor komponen dengan skor konstruk) indikator - indikator yang mengukur konstruk tersebut. Rule of thumb yang digunakan untuk validitas konvergen adalah outer loading > 0.7, communality > 0.5 dan Average Variance Extracted (AVE) $>0.5$. Rule of thumb untuk membuat pemeriksaan awal dari matrik faktor adalah \pm 0.30 artinya dipertimbangkan telah memenuhi level minimal, untuk loading \pm 0.40 dianggap lebih baik, dan untuk loading $>0.50$ dianggap signifikan secara praktikal. Semakin tinggi nilai faktor loading, semakin penting peranan loading dalam menginterpretasikan matrik faktor. Jogiyanto (2016), apabila skor loading $<0,5$ indiktor ini dapat dihilangkan dari konstruknya karena indikator ini tidak terhitung (load) ke konstruk yang mewakilinya. Apabila skor loading berkisar pada nilai 0,5 0,7 indikator masih dapat digunakan dengan syarat bahwa nilai AVE dan Communality indikator dimaksud bernilai >0,5.Chin (1998) dalam Ghozali (2015), hasil uji validitas konvergen pada model indikator reflektif, apabila nilai loading faktornya > 0,7 maka disifatkan sebagai indikator confirmatory, sedangkan apabila nilai loading faktornya 0,6 - 07 maka disifatkan sebagai indikator exploratory.

\section{b) Validitas diskriminan}

Validitas diskriminan berkaitan dengan prinsip bahwa pengukuran konstruk yang berbeda seharusnya tidak berkorelasi dengan tinggi. Validitas diskriminan terjadi jika dua instrumen yang berbeda yang mengukur dua konstruk yang diprediksi tidak berpengaruh dan menghasilkan skor yang memang tidak ada keterkaitannya. Nilai uji ini berupa nilai cross loadingyang untuk melihat apakah konstruk memiliki diskriminan yang memadai. Untuk menilai validitas diskriminan dapat juga 
dilakukan dengan membandingkan akar AVE untuk setiap konstruk dengan korelasi antara konstruk dengan konstruk lainnya dalam model.

\section{2) Uji Reliabilitas}

Reliabilitas menggambarkan ketepatan suatu alat ukur melakukan pengukuran. Uji reliabilitas terhadap indikator reflektif dilakukan dengan melihat nilai Cronbach's alpha dan Composite reliability. Nilai Cronbach's alpha mengukur batas bawah nilai reliabilitas suatu konstruk. Nilai Composite reliability mengukur nilai sesungguhnya reliabilitas suatu konstruk. Namun, Composite reliability dinilai lebih baik dalam mengestimasi konsistensi internal suatu konstruk. Rule of thumb nilai alpha atau Composite reliability harus lebih besar dari 0,7 meskipun nilai 0,6 masih dapat diterima. Namun, sesungguhnya uji konsistensi internal tidak mutlak untuk dilakukan jika validitas konstruk telah terpenuhi, karena konstruk valid adalah konstruk yang reliabel, sebaliknya konstruk yang reliabel belum tentu valid.

\section{b. Evaluasi Inner Model}

Inner model dalam PLS dianalisis dengan menggunakan nilai $R$ Square $\left(\mathrm{R}^{2}\right)$ untuk konstruk dependen, nilai koefisien path atau t-values tiap path untuk uji signifikansi antar konstruk dalam model struktural. Nilai $\mathrm{R}^{2}$ digunakan untuk mengukur tingkat variasi perubahan variabel independen terhadap variabel dependen. Semakin tinggi nilai $\mathrm{R}^{2}$ berarti semakin baik model prediksi dari model penelitian yang diajukan.

Nilai koefisien path atau inner modelmenunjukkan tingkat signifikansi dalam pengujian hipotesis. Skor koefisien path atauinner model yang ditunjukkan oleh nilai T-Statistic, harus di atas 1,96 untuk hipotesis dua ekor (two-tailed) dan di atas 1,64 untuk hipotesis satu ekor (one-tailed) untuk pengujian hipotesis pada alpha 5 persen.

\section{Hasil dan Pembahasan}

\subsection{Model Pengukuran (Outer Model)}

Model pengukuran pada penelitian ini menggunakan indikator reflektif pada semua peubah laten, dimana indikator bersifat perwujudan terhadap konstruk, apabila indikator berubah maka tidak akan berdampak pada kontsruk sedangkan jika konstruk berubah berdampak pada perubahan indikator, menghilangkan satu indikator tidak akan mengubah makna konstruk dan dianalisis dengan menggunakan convergent validity dan composite reliability (Ghozali 2015).

Tabel 4. Nilai Outer Loading

\begin{tabular}{|c|c|c|c|}
\hline Indikator & LO & IS & DS \\
\hline BO (Budaya Organisasi) & 0,706 & & \\
\hline KL (Kolaborasi) & 0,739 & & \\
\hline KN (Konektivitas) & 0,843 & & \\
\hline KOM (Kompetensi) & 0,774 & & \\
\hline KP (Kepemimpinan) & 0,661 & & \\
\hline KS (Knowledge Sharing) & 0,647 & & \\
\hline GB (Gagasan/Ide Baru) & & 0,739 & \\
\hline PB (Prosedur Baru) & & 0,742 & \\
\hline PI (Perilaku Inovatif) & & 0,869 & \\
\hline SK (Solusi Kreatif) & & 0,822 & \\
\hline UKOM (Kompetitif) & & & 0,910 \\
\hline UKOP (Komparatif) & & & 0,902 \\
\hline
\end{tabular}


Berdasarkan tabel 4. Nilai outer loading diatas tampak bahwa terdapat 10 indikator yang dengan nilai outer loading $>0,7$ dan 2 indiaktor dengan nilai outer loading < 0,7. Jogiyanto (2016); apabila nilai outer loading $<0,5$ indiktor ini dapat dihilangkan dari konstruknya karena indikator ini tidak terhitung (load) ke konstruk yang mewakilinya. Apabila skor loading berkisar pada nilai 0,5 - 0,7, indikator masih dapat digunakan karena dengan syarat bahwa nilai AVE dan Communality indikator bernilai $>0,5$ sesuai dengan data pada tabel 5 dibawah ini:

Tabel 5. Nilai Average Variance Extracted (AVE)

\begin{tabular}{cc}
\hline Variabel & Nilai AVE \\
\hline Daya_Saing & 0,821 \\
\hline Innovation_Strategy & 0,631 \\
\hline Learning_Organization & 0,535 \\
\hline
\end{tabular}

Berdasarkan hasil perhitungan Construct Reliability and Validityyang dideskripsikan pada tabel 4, diketahui bahwa nilai AVE konstruk LO > 0,5 maka 2 indikator pada konstruk LO $<0,7$ yaitu Kepemimpinan (KP) sebesar 0,661 dan Knowledge Sharing (KS) sebesar 0,647 yang memiliki nilai outer loading antara 0,5 - 0,7 dan skor AVE > 0,5 maka 2 indikator ini tidak dihilangkan sehingga secara keseluruhan seluruh indikator dapat dinilai signifikan secara praktikal. Pada variabel LO nilai outer loading paling tinggi yaitu variabel Konektivitas (KN). Pada variabel IS nilai outer loading paling tinggi yaitu dimensi Perilaku Inovatif (PI). Pada variabel DS nilai outer loading paling tinggi yaitu dimensi Keunggulan Kompetitif (UKOM).

Tabel 6. Validitas Diskriminan

\begin{tabular}{lccc}
\hline Vaiabel & Daya_Saing & Innovation Strategy & Learning Organization \\
\hline Daya_Saing & 0,906 & & \\
\hline Innovation_Strategy & 0,730 & 0,795 & \\
\hline Learning_Organization & 0,475 & 0,599 & 0,731 \\
\hline
\end{tabular}

Ghozali (2015) menyatakan bahwauji validitas dapat dianalisis dari hasil uji discriminant validity dengan melihat perbandingan nilai akar kuadrat AVE terhadap nilai korelasi antar variabel. Berdasarkan data pada tabel 6di atas diketahui bahwa hasil nilai akar kuadrat AVE seluruhnya lebih besar dar nilai korelasi masing-masing variabel, sehingga disimpulkan bahwa model peneletian valid memenuhi uji discriminant validity.

Tabel 7. Uji Reliabilitas

\begin{tabular}{lccc}
\hline & Cronbach's Alpha & rho_A & Composite Reliability \\
\hline Daya_Saing & 0,781 & 0,782 & 0,901 \\
\hline Innovation_Strategy & 0,804 & 0,809 & 0,872 \\
\hline Learning_Organization & 0,825 & 0,843 & 0,873 \\
\hline
\end{tabular}

Uji reliabilitas dianalisis dari nilai Cronbach's alpha dan nilai Composite Reliability dilakukan untuk mengetahui bahawa suatu konstruk bersifat reliable, apabila nilai Cronbach's alpha> 0,6 dan nilai Composite Reliability> 0,7. Berdasarkan hasil perhitungan pada tabel 7 di atas, ketahui bahwa variabel LO, IS, dan DS memiliki nilai Cronbach's alpha> 0,6. Demikian juga dengan hasil perhitungan Composite reliability, diketahui bahwa variabel LO, IS, dan DS nilai Composite reliability> 0,7. Disimpulkan seluruh variabel dalam model ini yaitu LO, IS, dan DS telah reliabel, memenuhi uji reliabilitas dimana variabel-variabel tersebut dapat menghasilkan pengukuran yang konsisten. 


\subsection{Model Struktural (Inner Model)}

Model struktural menganalisis hubungan antar variabel laten. pengujian struktural (inner model) dilakukan melalui dua pengujian. Pertama, uji inner model dengan mengukur signifikansi koefisien jalur sebagai gambaran hubungan dan pengaruh antar variabel laten. Kedua, uji $\mathrm{R}$ sequare $\left(\mathrm{R}^{2}\right)$ dengan analisis uji Googness-Fit model. Nilai $\mathrm{R}^{2}$ mendeskripsikan pengaruh variabel laten independen terhadap variabel laten dependen apakah mempunyai dampak yang substantif (Ghozali 2015).Pada pengujian pertama, pengujian dilakukan dengan menyandingkan nilai $\mathrm{T}$ statistik dengan nilai $\mathrm{T}$ tabel. Nilai koefisien path atau inner model mengindikasikan nilai signifikansi dalam pengujian hipotesis. Nilai koefisien path atau inner model yang ditunjukkan oleh nilai T-statistik, disyaratkan memiliki nilai > 1,96 untuk hipotesis dua ekor (two-tailed) untuk pengujian hipotesis pada alpha 5 persen. Kesimpulan yang diambil bila nilai $\mathrm{T}$ Statistik lebih besar $\mathrm{T}$ tabel menunjukkan ada pengaruh signifikan antara varibel laten, dan sebaliknya bila nilai T Statistik lebih kecil menunjukkan tidak ada pengaruh signifikan antar variabel laten. Hasil analisis pengujian model struktural disajikan pada tabel 8 sebagai berikut:

Tabel 8. Tabel Perhitungan Inner Model

\begin{tabular}{lccccc}
\hline \multicolumn{1}{c}{ Pengaruh } & $\begin{array}{c}\text { Original } \\
\text { Sample }(\mathrm{O})\end{array}$ & $\begin{array}{c}\text { Sample } \\
\text { Mean (M) }\end{array}$ & $\begin{array}{c}\text { Standard Deviation } \\
(\text { STDEV })\end{array}$ & $\begin{array}{c}\text { T Statistics } \\
(\mid \mathrm{O} / \text { STDEV } \mid)\end{array}$ & Keputusan \\
\hline LO $\rightarrow$ DS & 0,059 & 0,061 & 0,076 & 0,773 & $\mathrm{H}_{1}$ ditolak \\
\hline IS $\rightarrow$ DS & 0,694 & 0,694 & 0,064 & 10,848 & $\mathrm{H}_{2}$ diterima \\
\hline LO $\rightarrow$ IS $\rightarrow$ DS & 0,416 & 0,422 & 0,054 & 7,682 & $\mathrm{H}_{3}$ diterima \\
\hline LO $\rightarrow$ IS & 0,599 & 0,608 & 0,053 & 11,282 & $\mathrm{H}_{4}$ diterima \\
\hline
\end{tabular}

Pengujian kedua melalui uji $\mathrm{R}^{2}$, nilai $\mathrm{R}^{2}$ untuk menganalisis tingkat keberagaman perubahan variabel independen terhadap variabel dependen. Semakin tinggi nilai $\mathrm{R}^{2}$ berarti semakin baik model prediksi dari model penelitian yang diajukan.

Tabel 9. Nilai R Square

\begin{tabular}{lc}
\hline & R Square \\
\hline DS & 0,534 \\
\hline IS & 0,359 \\
\hline
\end{tabular}

Berdasarkan data pada tabel 9, nilai $\mathrm{R}^{2}$ variabel laten DS sebesar 0,534 menunjukkan bahwa variabel laten DS dapat dianalisis melalui variabel laten LO sebesar 53,40\% sedangkan 46,60\% dianalisis oleh variabel lain yang tidak diteliti dalam penelitian ini. Nilai $\mathrm{R}^{2}$ variabel IS sebesar 0,359 yang artinya variabel laten IS dapat dianalisis oleh LO sebesar 35,90\% sedangkan 64,10\% dianalisis oleh variabel lain yang tidak diteliti dalam penelitian ini. Menutur Chin (1998); yang disetasi Ghozali (2015); disimpulkan bahwa hasil analisis terhadap nilai $\mathrm{R}^{2}$ untuk peubah laten DS dan IS dapat dikategorikan dalam kelompok moderat dan baik (diantara 0,33 sampai dengan 0,67). Model struktural PLS yang digambarkan pada gambar 2 sebagai berikut. 


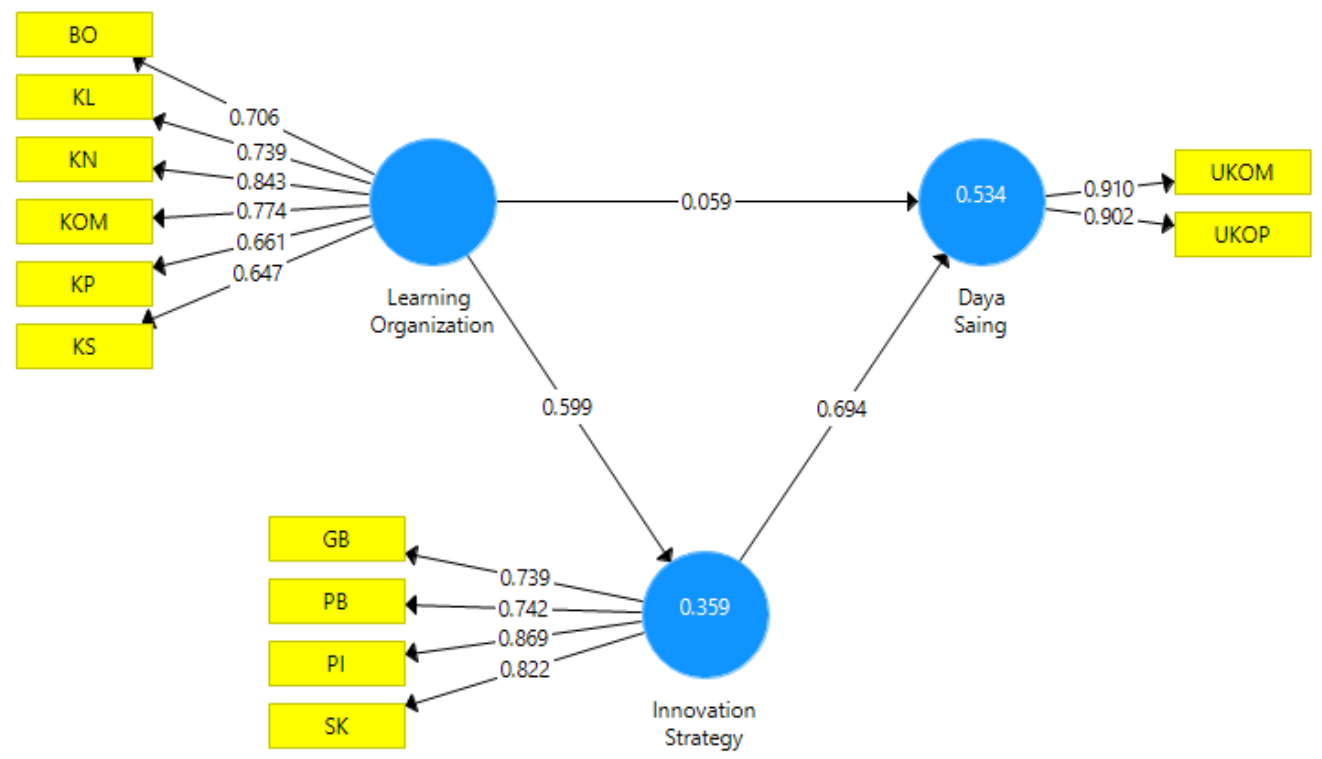

Gambar 2. Model Struktural PLS (Path Diagram)

\subsection{Pengaruh Learning Organizationterhadap Daya Saing Budidaya Bawang Putih.}

Berdasarkan analisis dalam pengolahan data penelitian menunjukkan tidak ada pengaruh langsung Learning Organization terhadap Daya Saing bawang putih karena nilai T Statistik pada pengaruh Learning Organization terhadap Daya Saing bawang putih lebih kecil nilai T Tabel 1,96 (tidak signifikan) yaitu sebesar 0,773. Meskipun variabel Learning Organization tidak berpengaruh langsung terhadap Daya Saing, variabel ini berpengaruh signifikan terhadap Innovation Strategy. Penerapan Learning Organization tidak akan secara langsung meningkatkan daya saing karena penerapan Learning Organization lokus pada dinamika kelompok tani dan kapabilitas petani itu sendiri. Sedangkan Daya Saing bawang putih banyak dipengaruhi oleh keunggulan kompetitif dan komparatif bawang putih.

Apabila dilihat dari aspek indikator yang mendukung variabel Learning Organization, terdapat 6 indikator pada variabel Learning Organization, di mana dari keenam indikator tersebut, terdapat 4indikator yang memiliki nilai loading faktor> 7,0 yaitu Budaya Organisasi, Kolaborasi/Kerjasama, Konektivitas/Jejaring, dan Kompetensi yang berarti valid dan terdapat 2 indikator yang menghasilkan loading faktor <7,00. Menurut Hair et.al (2011); bawah indikator yang nilai loading faktornya $>6,0$ masih dapat diterima sehingga 2 indikator yaitu Kepemimpinan dan Knowledge Sharing masih dapat diterima sebagai indikator yang mempengaruhi variabel Learning Organization.

Nilai R square pada variabel Learning Organization terhadap Daya Saing bawang putih 0,534 yang berarti bahwa variasi perubahan variabel Daya Saing bawang putih yang dapat dijelaskan oleh Learning Organization sebesar 53,40\%. 


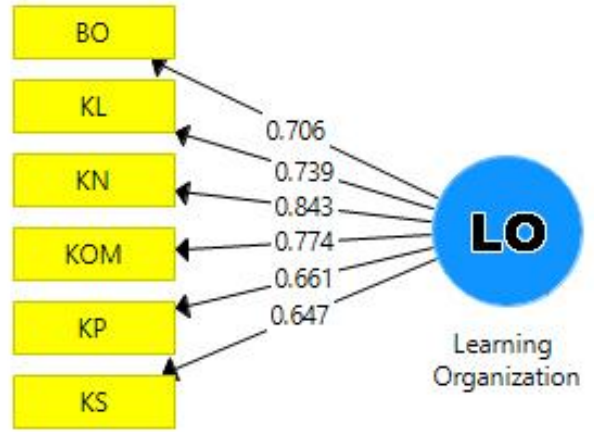

Gambar 3. Nilai Koefisien Indikator Learning Organization

Indikator variabel yang berpengaruh paling kuat sesuai dengan gambar 3 di atas adalah Konektvitas/Jejaring (KN) dengan nilai loading faktor 0,843 . Konektvitas/Jejaring (KN) bagi kelompok tani menjadi hal yang sudah biasa dilakukan khususnya dalam penggunaan sarana teknologi dalam berhubungan dan berkomunikasi melalui Whatapps (WA), SMS, dan Facebook. Konektvitas/Jejaring juga dilakukan dalam berbagai aktivitas organsisi yang ada di lingkungan seperti pengajian, pertemuan rutin kelompok tani, arisan, dan paguyuban. Hal ini menunjukkan bahwa kelompok tani sudah memanfaatkan teknologi komunikasi modern (HP) sebagai media bersosilaisasi. Akan tetapi dari data olah responden, diketahui bahwa penggunaan media TV dan Radio mulai ditinggalkan oleh kelompok tani dalam berhubungan, yang ditunjukkan dengan nilai rata-rata rendah dalam penggunanan media tersebut. Indikator Konektivitas apabila dicermati secara grafik atas persepsi yang diperoleh dari responden adalah sebagai berikut:

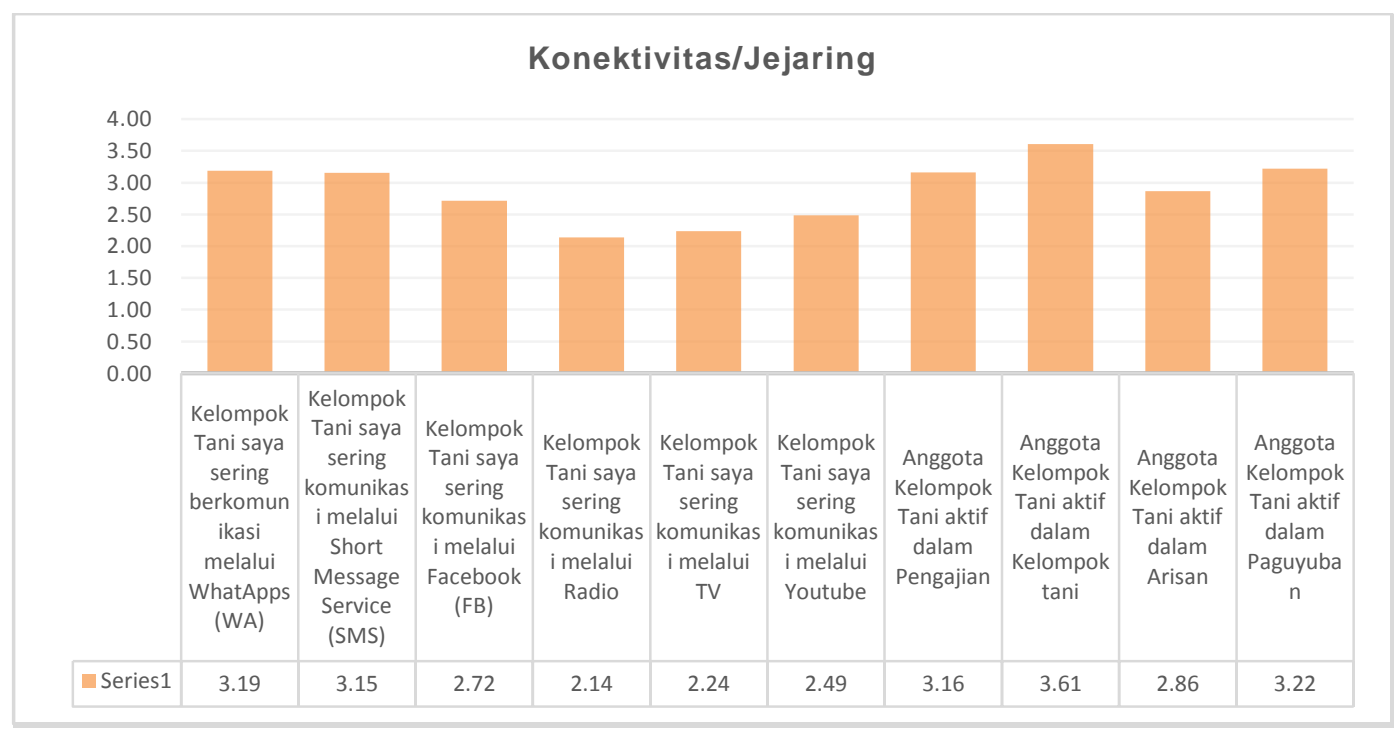

Gambar 4. Grafik Persepsi Konentivitas (KN)

Berdasarkan grafik pada gambar 4 diatas diketahui bahwa Konektivitas menjadi indikator terkuat pada varibel Learning Organization, dimana interaksi/keaktifan Kelompok Tani dalam kegiatan-kegiatan kelompok berpengaruh secara kuat pada terbentuknya Konektivitas/Jejaring. Didukung adanya Paguyuban Kelompok Tani atau yang biasa disebut dengan istilah Gapoktan/Selapanan, maka interaksi Kelompok Tani menjadi lebih luas cakupannya. Teknologi informasi yang berkembang juga memberikan konribusi pada terbentuknya Konektivitas/Jejaring dengan komunikasi menggunakan Whatapps, SMS, dan Facebook 
Indikator variabel terkuat kedua adalah Kompentesi dengan nilai loading faktor sebesar 0,774 dimana pengetahuan kelompok tani tentang budidaya bawang putih telah banyak dimiliki oleh para petani sehingga mereka meyakini bahwa budidaya bawang putih yang diusahakan akan memberikan keuntungan. Meskipun demikian, kelompok tani juga masih menghadapi kesulitankesulitan tertentu yang terkait dengan tatakelola budidaya bawang putih.

Indikator variabel Kolaborasi memiliki nilai loading faktor 0,739 dimana indikator ini menunjukkan bahwa kelompok tani telah membangun kolaborasi/kerjasama baik dilaksanakan oleh sesama kelompok seperti kerjasama kelompok tani dengan penangkar benih, atau kolaborasi/kerjasama kelompok tani dengan kemitraan importir bawang putih. Kerjasama yang belum intens dilakukan adalah kerjasama dengan lembaga keuangan. Dua indikator variabel lainnya adalah Kepemimpinan dan Knowledge Sharing yang memperoleh hasil skor loading faktor masing-masing 0,661 dan 0,647. Pada aspek Kepemimpinan, faktor kepercayaan terhadap pemimpin baik di tingkat kelompok tani maupun masyarakat (tokoh masyarakat) masih menjadi pertimbangan dalam pengambilan keputusan kelompok tani. Knowledge sharing yang diwujudkan dalam proses berbagi pengetahuan dan informasi yang dominan dilakukan dalam hal pengolahan lahan, pengendalian organisme penggangu tanaman, dan program-program pembinaan petani/bantuan pemerintah. Ketiga tema ini yang paling sering menjadi bahan pembahasan dalam pertemuan rutin (selapanan) kelompok tani.

\subsection{Pengaruh Innovation Strategyterhadap Daya Saing Budidaya Bawang Putih.}

Berdasarkan analisis dalam pengolahan data penelitian menunjukkan bahwa terdapat pengaruh signifikan Innovation Strategy terhadap daya saing bawang putihditunjukkan dengan pengaruh Innovation Strategy terhadap Daya Saing bawang putih dengan nilai T-Statistik sebesar 11,282. Apabila dibandingkan dengan T Tabel, nilai tersebut lebih besar dari 1,96. Dari seluruh indikator variabel Innovation Strategy, keempat indikator variabel Innovation Strategy memiliki nilai loading faktor > 7,0 yaitu Implementasi Ide/Gagasan Baru, Implementasi Prosedur/Teknik Budidaya Baru, Perilaku Inovatif, dan Penerapan Solusi Kreatif Terhadap Masalah, yang berarti keempat indikator tersebut valid. Hasil perhitungan $\mathrm{R}$ square pada variabel Innovation Strategy sebesar 0,359 menunjukkan perubahan variabel Innovation Strategy yang dapat dianalisis oleh Learning Organization sebesar 35,9\%. Indikator variabel yang berpengaruh paling kuat adalah Perilaku Inovatif Memanfaatkan Teknologi yang diwujudkan dalam bentuk penggunaan teknologi-teknologi tepat guna yang bermanfaat dalam budidaya bawang putih dan pengolahan pasca panen bawang putih.

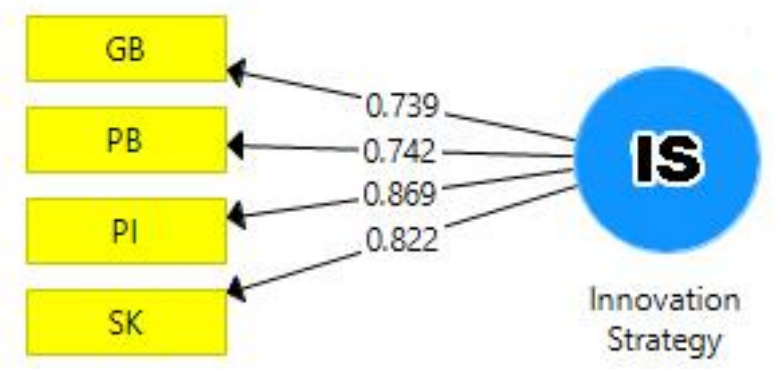

Gambar 5. Nilai Koefisien Indikator Innovation Strategy

Indikator variabel yang berpengaruh paling kuat sesuai gambar 5 di atas adalah Perilaku Inovatif (PI) Memanfaatkan Teknologi yang diwujudkan dalam bentuk penggunaan teknologiteknologi tepat guna yang bermanfaat dalam budidaya bawang putih dan pengolahan pasca panen bawang putih. Indikator lainnya yang juga memiliki pengaruh kuat kedua pada Innovation Strategy adalah Penerapan Solusi Kreatif Terhadap Masalah yang dihadapi pada budidaya 
bawang putih. Kelompok tani senantiasa berbagi pengalaman dalam menghadapi kedala dalam budidaya bawang putih misalkan cara penanggulangan organisme pengganggu tanaman seperti nematoda yang sering merugikan petani, antisipasi tanaman yang sudah tumbuh menjadi layu, dan upaya penggunaan pupuk organik/fermentasi dalam budidya bawang putih. Implementasi Ide/Gagasan Baru dan Implementasi Prosedur Teknik Budidaya baru telah dilakukan pada kelompok-kelompok tani yang memiliki alat dan mesin pertanian yang memadai. Ide-ide baru yang muncul diispirasi oleh kegiatan-kegiatan studi banding yang pernah diikuti oleh anggota Kelompok Tani ke daerah lain misalkan dalam hal pengolahan pasca panen (garlic powder, black garlic, coffee garlic), proses penanganan pasca panen seperti proses pengeringan dan penyimpanan (storage) serta pemasaran melalui membuka peluang pasar baru untuk mengembagkan pasar bawang putih yang sudah ada.

Indikator yang juga kuat berpengaruh adalah Penerapan Solusis Kreatif Dalam Menyelesaikan Masalah, dimana indikator ini mengarah kreativitas kelompok tani dalam menghadapi kendala-kendala dalam tatakelola bawang putih di arahkan dengan mencari solusi yang kreatif. Indikator Perilaku Inovatif dalam menggunakan teknologi dan Solusi Kreatif Dalam Menghadapi Masalah apabila dicermati secara grafik atas persepsi yang diperoleh dari responden adalah sebagai berikut:

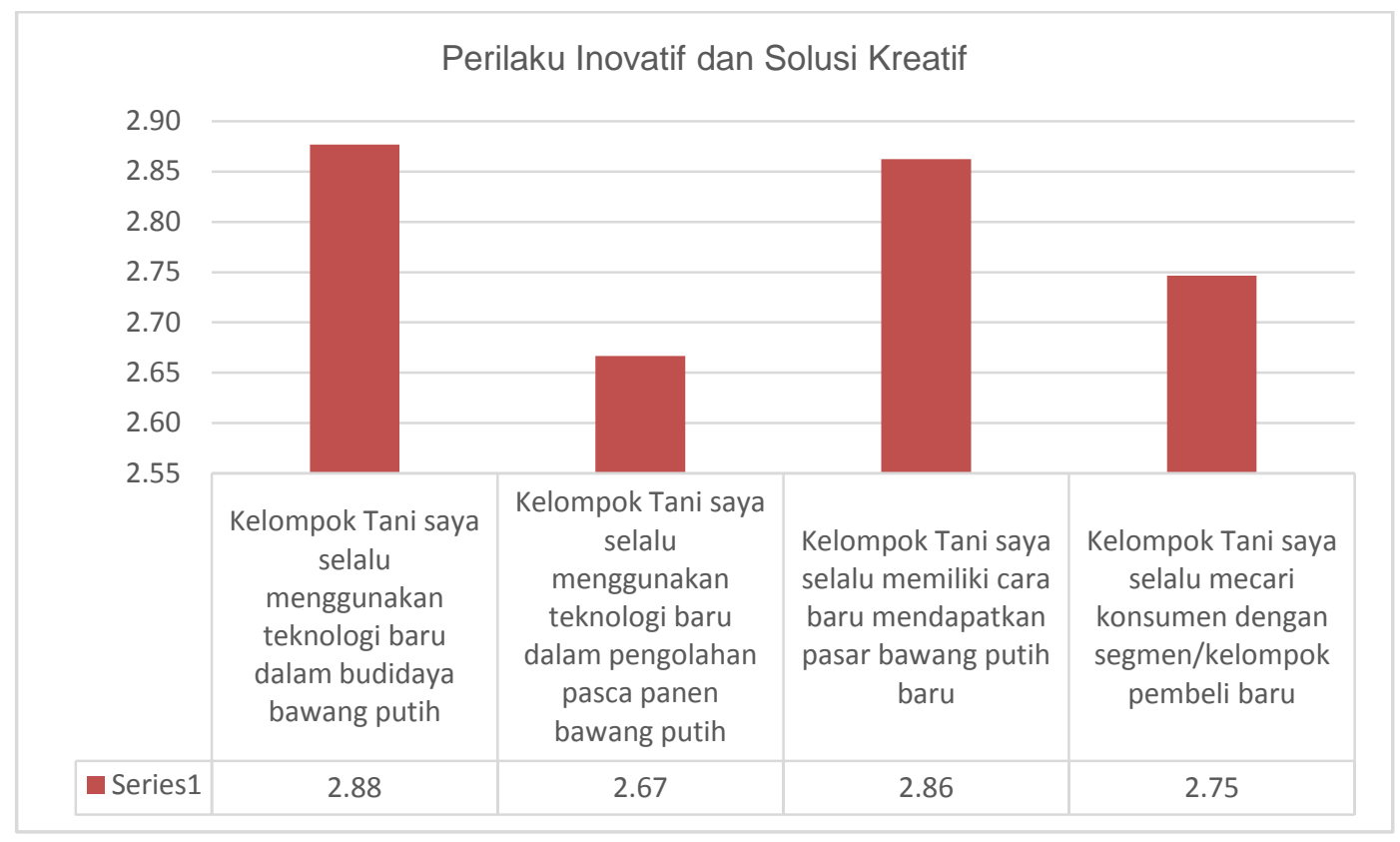

Gambar 6. Grafik Persepsi Perilaku Inovatif dan Solusi Kreatif

Berdasarkan grafik pada gambar 6 diatas diketahui bahwa Perilaku Inovatif dalam menggunakan teknologi dan Solusi Kreatif Dalam Menghadapi Masalah adalah faktor terkuat mempengaruhi Innovation Strategi. Perilaku Inovatif dalam menggunakan teknologi dan Solusi Kreatif Dalam Menghadapi Masalah terlihat pada adanya teknologi baru yang digunakan dalam budidaya bawang putih dan cara-cara baru dalam menciptakan pasar bagi penjualan hasil panen bawang putih.

Dari hasil pengamatan terhadap perilaku yang dikembangkan oleh Kelompok Tani Bawang Putih, diketahui terdapat teknologi baru yang digunakan dalam budidaya bawang putih diterapkan seperti pada pemanfaatan pupuk fermentasi yang bersumber dari limbah kulit kopi yang tersedia dalam jumlah banyak dan mudah didapatkan di wilayah Kabupaten Temanggung 
mengingat daerah tersebut juga sebagai daerah sentra tanaman kopi. Inovasi ini diperoleh karena adanya interaksi sesama kelompok tani dalam forum Paguyuban/Selapanan. Diperdalam dengan peningkatan pemahanam petani yang tidak enggan belajar melalui media sosial (Group WA dan Facebook) mengingat bahwa usia rata-rata Kelompok Tani sesuai data responden $46 \%$ usia 36 45 tahun dan $23 \%$ usia 25 - 35 tahun, artinya sebagian besar dari kelompok tani didominasi usia muda yang mudah dalam beradaptasi dengan teknologi informasi.

Terkait dengan cara-cara baru dalam menciptakan pasar baru bagi penjualan hasil panen bawang putih terlihat dengan adanya inovasi dalam cara mengedukasi dan membuat sosialisasi tentang diversifikasi produk bawang putih. Pada Kelompok Wanita Tani (KWT) yang anggotanya seluruhnya adalah perempuan, dalam setiap aktivitas pertemuan Paguyuban/Selapanan, selain pertemuan rutin yang membahas mengenai budidaya bawang putih pada masing-masing kelompok tani, juga diadakan workshop pengolahan pasca panen bawang putih untuk meningkatkan nilai tambah bawang putih juga untuk menciptakan pasar baru produk olahan bawang putih. Sebagai contoh yang sudah dikembangkan garlic powder, black garlic, dan coffee garlic.

\subsection{Pengaruh Learning Organizationterhadap Daya Saing Budidaya Bawang PutihmelaluiInnovation Strategy}

Berdasarkan analisis dalam pengolahan data penelitian menunjukkan bahwa terdapat pengaruh positif Learning Organizationtidak langsung terhadap Daya Saing bawang putih melalui Innovation Strategy ditunjukkan dengan nilai T-Statistik Specific Indirect Effect LO $\rightarrow$ IS $\rightarrow$ DS sebesar 7,682. Apabila dibandingkan dengan nilai T Tabel, nilai tersebut lebih besar dari 1,96.

Nilai R square berdasarkan tabel Specific Indirect Effect LO $\rightarrow$ IS $\rightarrow$ DS sebesar 0,416 menunjukkan bahwa variasi perubahan variabel Daya Saing yang dapat dianalisis oleh Learning Organization secara tidak langsung melalui Innovation Strategy sebesar $41,60 \%$. Nilai path koefisien Pengaruh langsung Learning Organization terhadap Daya Saing menunjukkan angka 0,059 sedangkan pengaruh tidak langsung Learning Organization Terhadap Daya Saing melalui Innovation Strategy menunjukkan angka 0,416. Berdasarkan hal tersebut, nilai koefisien pengaruh tidak langsung lebih besar daripada koefisien pengaruh langsung, sehingga Innovation Strategy memediasi pengaruh antara Learning Organization terhadap Daya Saing.

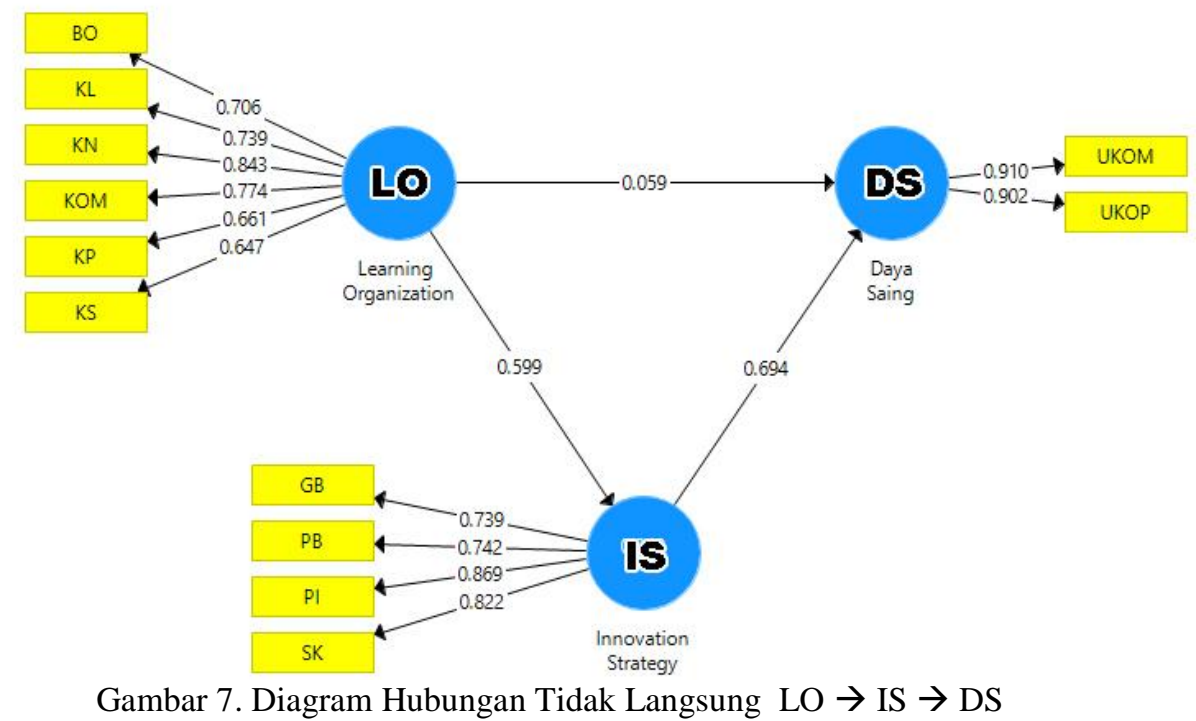


Berdasarkan gambar 7 diatas diketaui bahwa dorongan kelompok Tani dalam melakukan inovasi dalam aspek Sumber Daya Manusia (Petani) seperti Implementasi Ide/Gagasan Baru (GB), Implementasi Teknik Budidaya Baru (PB), Perilaku-Perilaku Inovatif (PI), dan Penerapan Solusi Kreatif Terhadap Masalah Tatakelola Bawang Putih (SK), hal-hal tersebut muncul sebagai dampak dari adanya penerapan Learning Organization seperti berbagi pengetahuan (KS) yang diperoleh pada saat pertemuan-pertemuan di tingkat Paguyuan Gabungan Kelompok Tani yang merupakan wujud jejaring/konektivitas (KN) antara kelompok tani dan Budaya Organisasi (BO). Teknologi Informasi yang juga memudahkan kelompok tani dalam berbagai pengetahuan dimanfaatkan sebagai sarana yang efektif untuk meningkatkan kompetensi (KOM) dan pengetahuan (KP) dan kerjasama/kolabirasi (KL) antara kelompok tani. Secara tidak langsung, hal-hal yang dilakukan kelompok tani dalam penerapan Learning Organization (Konektivitas/Jejaring, Kompetensi, Kolaborasi, dan Budaya Organosasi yang kuat) akan berpengaruh pada Daya Saing Bawang Putih melalui Innovation Strategy. Mengembangkan Learning Organization melalui input produksi dan sumber daya manusia tidak akan secara langsung meningkatkan Daya Saing Bawang Putih melainkan akan meningkatkan Innovation Strategy terlebih dahulu yang dalam proses selanjutnya akan meningkat Daya Saing Bawang Putih itu sendiri.

\subsection{Pengaruh Learning OrganizationterhadapInnovation Strategy}

Berdasarkan analisis dalam pengolahan data penelitian menunjukkan bahwa terdapat pengaruh signifikan Learning Organization terhadap Innovation Strategy. Hasil perhitungan diperoleh nilai inner weight pengaruh Learning Organization terhadap Innovation Strategy didapatkan nilai TStatistik sebesar 11,282. Apabila dibandingkan dengan T Tabel, nilai tersebut lebih besar dari 1,96. Pada perkiraan hasil perhitungan pengaruh LO - IS menunjukkan angka 0,599 artinya terdapat pengaruh positif Learning Organization terhadap Innovation Strategy. Setiap perubahan variabel Innovation Strategy dapat dianalisis oleh Learning Organization sebesar 59,9\%. Indikator pada variabel Learning Organization merupakan pendukung terbentuknya Innovation Strategy. Innovation Strategy akan terbentuk manakala penerapan Learning Organization berjalan dalam kelompok tani.

Konektivitas/Jejaring yang dibentuk oleh kelompok tani melalui Paguyuban/Selapanan kelompok tani menjadi sarana bagi setiap anggota dalam kelompok tani untuk saling berbagi pengetahuan, pengalaman, dan inovasi. Hal-hal baru apa saja yang sudah dilakukan oleh kelompok tani lain dalam mengembangkan masalah budidaya, pemasaran, dan pengembangan bawang putih akan memotivasi dan menumbuhkan keiinginan untuk berinovasi pada kelompok lainnya. Dengan kemudahan dalam berbagi informasi melalui group WA, media edukasi yang dishare di YouTube dan Facebook memudahkan setiap kelompok tani untuk mengembangkan kemampuan berinovasi baik dengan cara menduplikasi atau mengembagkan ide atau gagasan baru. Hal inilah sebagai salah satu bentuk Perilakuk Inovatif yang dikembangkan oleh kelompok tani.

\section{Kesimpulan}

Berdasarkan hasil penelitian tersebut disimpulkan bahwa penerapan Learning Organization tidak berpengaruh langsung terhadap daya saing bawang putih. Penerapan Innovation Strategy berpengaruh langsung terhadap daya saing bawang putih.Penerapan Learning Organization berpengaruh tidak langsung terhadap Daya Saing bawang putih melalui Innovation Strategy.Terdapat hubungan pengaruh langsung antara Learning Organization dan Innovation Strategy. Implikasi dari studi ini dapat diterapkan dalam kebijakan pemberian bantuan sosial (bansos) pemerintah berupa alat dan mesin pertanian (Alsintan), benih, pupuk, dan sarana/prasarana pengolahan pasca panen harus dilakukan pendampingan dan penguatan 
pengetahuan melalui transfer pengetahuan hasil-hasil penelitian (desiminasi hasil penelitian) agar memotivasi dan menumbuhkan inovasi dalam budidaya bawang putih sehingga mampu meningkatkan daya saing produk bawang putih tersebut. Pola-pola pemberdayaan kelompok tani melalui penyuluhan menjadi kunci dalam proses Learning Organization karena pada saat interaksi penyuluh dan anggota kelompok tani akan mampu menumbuhkan minat pembelajaran baik melalui tatap muka maupu melalui media komunikasi lainnya seperti Youtube dan media online lainnya.

\section{Saran}

Untuk meningkatkan Daya Saing bawang putih di kabupaten Temanggung dapat dilakukan dengan meningkatkan Strategi Inovasi (Innovation Strategy) pada kelompok tani melalui optimalisasi proses organisasi pembelajar (Learning Organization) di dalam kelompok tani.Upaya peningkatan Strategi Inovasi (Innovation Strategy) pada aspek sumber daya kelompok tani dapat dilakukan memunculkan perilaku inovatif dan penerapan solusi kreatif atas setiap kendala yang dihadapi melalui penggunaan teknologi informasi tepat guna dalam budidaya dan pengolahan paska panen bawang putih.Proses Learning Organization akan lebih berpengaruh secara signifikan apabila diimplementasikan mendukung strategi inovasi. Proses Learning Organization yang paling berpengaruh adalah membangun konektivitas/jejaring antar kelompok tani untuk saling berbagi pengetahuan dan pengalaman sehingga akan meningkatkan kompetensi SDM kelompok tani. Konektivitas dan kompetensi yang baik akan mampu meningkatkan daya saing khususnya apabila kolaborasi/kerjasama antar kelompok tani juga terbangun dengan baik.

\section{Ucapan Terimakasih}

Terima kasih kepada Bapak Dr. Ivan Yulivan, S.E., M.M., M.Tr.(Han)., CHRMP, selaku Dosen Pembimbing I dan Ibu Dr. Jubaedah, S.E., M.M., selaku Dosen Pembimbing II yang telah banyak memberikan arahan dan saran-saran yang sangat bermanfaat. Terima kasih juga disampaikan kepada Dinas Pertanian dan Peternakan kabupaten Temanggung yang telah memberkan kemudahan akses dalam pengambilan data di kelompok tani bawang putih di wilayah kabupaten Temanggung. Ucapan terima kasih juga disampaikan kepada ibu, istri tercinta, anakanak tersayang serta seluruh keluarga yang tidak henti-hentinya memberikan semangat dan doa kepada penulis. Penulis juga menyampaikan terima kasih kepada seluruh pihak yang telah berkontribusi dalam membantu dalam penyelesaian penelitian ini.

\section{Daftar Pustaka}

Adrianto, Joko. 2016. Analisis Adopsi SRI (System Of Rice Intensification) dan Dampaknya Terhadap Efisiensi Usahatani Padi di Kabupaten Solok selatan. Tesis. Institut Pertanian Bogor. Bogor.

Badan Pusat Statistik, (2018) Kabupaten Temanggung Dalam Angka Tahun 2018, Edisi Agustus 2018

Buulolo, Progresif (2018), Pentingnya Inovasi dalam Meningkatkan Kinerja Koperasi, Jurnal Ilman, Vol. 6, No. 1, pp. 61-67, Februari 2018 p-ISSN 2355-1488, e-ISSN 2615-2932, http://journals.synthesispublication.org/index.php/ilman

Beyene, K.T, dkk (2016), The Impact Of Innovation Strategy On Organizational Learning And Innovation Performance: Do Firm Size And Ownership Type Make A Difference?, South African Journal of Industrial Engineering May 2016 Vol 27(1), pp 125-136

Erwidodo, M.S., Dr.Ir. (2015), Meningkatkan Daya Saing Produk Hortikultura: Strategi Menghadapi MEA 2015, Badan Litbang Pertanian, 2015 
Ghozali, Imam (2015), Partial Least Squares, Konsep, Teknik, dan Aplikasi Menggunakan Program SmartPLS 3.0 Untuk Penetian Empiris, Badan Penerbit Universitas Diponegoro, ISBN : 979.704.300.2

Hutabarat, (2014), Peningkatan Kinerja Pembangunan Pertanian Indonesia Tidak Semata-Mata Bertumpu Pada Daya Saing, IAARD PRESS, Jakarta.

Indrayani, N. K. A. dan Swara, I. W. Y. 2014. "Pengaruh Konsumsi, Produksi, Kurs Dollar AS Dan PDB Pertanian Terhadap Impor Bawang Putih Indonesia”. dalam E-Jurnal Ekonomi Pembangunan Universitas Udayana, 3 (5), h. 209-218

Jogiyanto HM. 2008. Metodologi Penelitian. Edisi I, Andi Offset, Yogyakarta.

KachAndrew, (2015), The Influence Of Different Knowledge Workers On Innovation Strategy And Product Development Performance In Small And Medium-Sized Enterprises, International Journal of Production Research,2015, Vol. 53, No. 8, 2489-2505, http://dx.doi.org/10.1080/00207543.2014.975856

Kementerian Pertanian, 2018, Peraturan Menteri Pertanian Republik Indonesia Nomor 03/Permentan/Sm.200/1/2018 Tentang Pedoman Penyelenggaraan Penyuluhan Pertanian, Kementerian Pertanian, Jakarta.

Kementerian Pertanian, 2015, Strategi Induk Pembangunan Pertanian Tahun 2015-2025, Kementerian Pertanian, Jakarta.

Kementerian Pertanian, 2015, Rencana Strategis 2015 - 2019, Kementerian Pertanian, Jakarta,

Pramono, J., Prastuti, T.R. dan Samijan. 2011. Intensifikasi Budidaya Bawang Putih. Balai Pengkajian Teknologi Pertanian Jawa Tengah. Semarang

Saptana, (2010), Micro-Macro Conceptual Review Of Competitiveness And Agricultural Development Strategy, Forum Penelitian Agro Ekonomi. Volume 28 No. 1, Juli 2010: 1 - 18, http://dx.doi.org/10.21082/fae.v28n1.2010.1-18

Sirait, Manuel, (2015), Pengaruh Learning Organization Dan Inovasi Terhadap Peningkatan Kinerja Ukm Di Kota Bogor, Jurnal Manajemen/Volume XIX, No. 02, Juni 2015: 290-303, Bogor, Jawa Barat.

West, Michael A. (1997). Developing Creativity in Organizations. The BritishPsychological Society; Leicester, UK

Tidd, J, Bessant, J. and Pavitt, K. 2001, ManagingInnovation: Integratiig Technological, Market andOrganisational Change, 2nd ed., Wiley, Chichester.

Nugroho, R. A. (2013), Identifikasi Kapabilitas Inovasi Dan Strategi BersaingSentra Usaha Kecil Logam Winongan Di Kabupaten Pasuruan,

Noor, Hana Fadhilah (2018), Analisis Strategi Manajemen Risiko PadaUsahatani Bawang Putih Di KelurahanKalisoro,Kecamatan Tawangmangu, KabupatenKaranganyarTahun 2018, Prosiding: ISSN: 2621 - 1572The National Conferences Management and Business (NCMAB), 2018.

Wardani, Aristiyana Nur Tri (2018), The Impact Of Gap-Sop On The Production And Technical Efficiency Of Garlic In Temanggung Regency, AGRO EKONOMI, Vol 29, Issue 2, December 2018, Page. 299-309DOI : http://doi.org/10.22146/ae.36468, ISSN 0215-8787 (print), ISSN 2541-1616 (online), Available at https://jurnal.ugm.ac.id/jae/ 